\title{
QA: $\mathbf{L}$
}

\section{Civilian Radioactive Waste Management System} Management \& Operating Contractor

\author{
Waste Handling Equipment \\ Development Test and Evaluation Study \\ BCBD00000-01717-5705-00007 Revision 00 DCN 1
}

November 25, 1998

Prepared for:

U.S. Department of Energy

Yucca Mountain Site Characterization Office

P.O. Box 98608

Las Vegas, NV 89193-8608

Prepared by:

TRW Environmental Safety Systems, Inc.

1261 Town Center Drive

Las Vegas, NV 89134

Under Contract Number

DE-AC08-91RW00134 
Civilian Radioactive Waste Management System

Management \& Operating Contractor

Waste Handling Equipment

Development Test and Evaluation Study

BCBD00000-01717-5705-00007 Revision 00 DCN 1

November 25, 1998

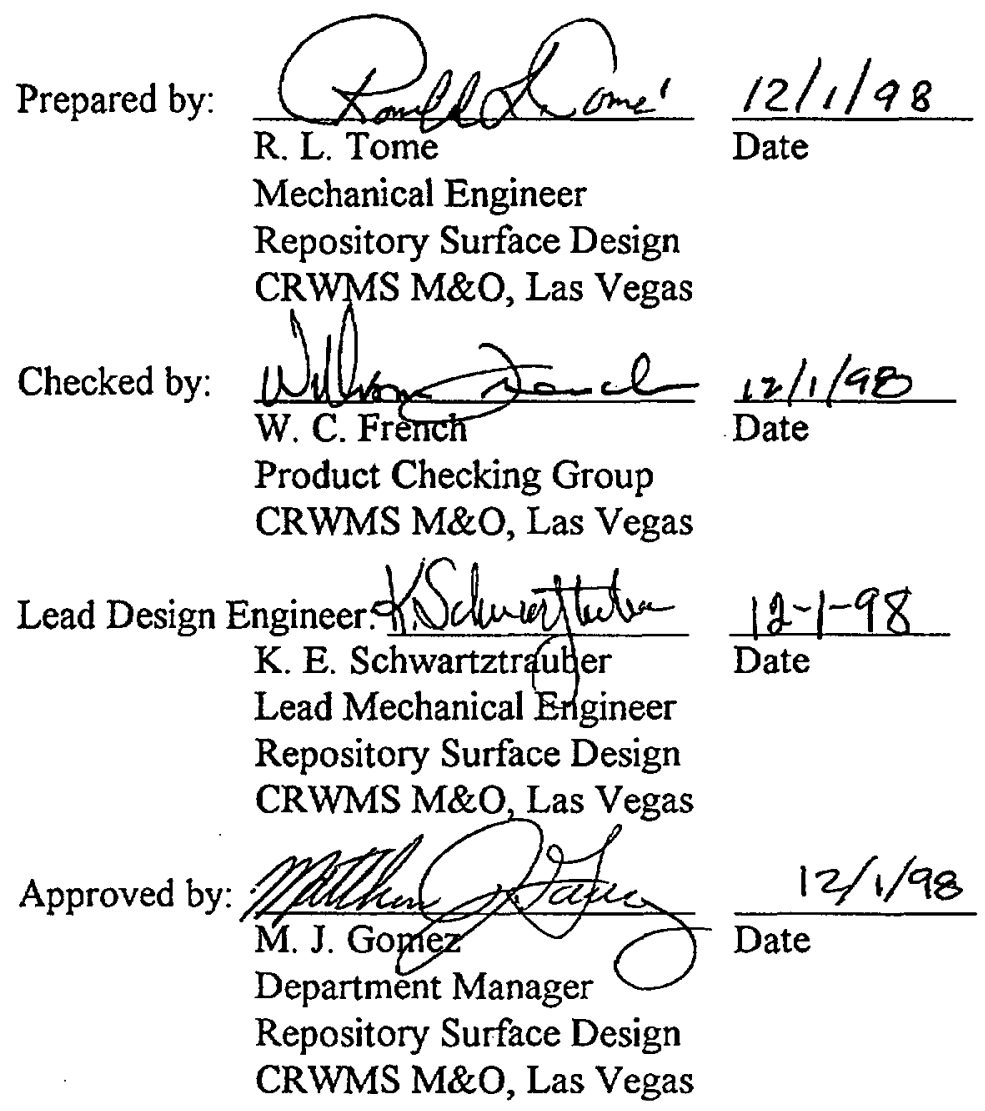




\section{History of Change Page}

\begin{tabular}{|l|l|}
\hline Revision No. & Description \\
\hline 00 & Initial Issue \\
\hline 00 DCN 1 & $\begin{array}{l}\text { Document Change Notice: Change only cover page, signature page, and replace Attachment I } \\
\text { in its entirety to incorporate DOE comments on YDAR \#20062. Add Page 2a as History of } \\
\text { Change Page. }\end{array}$ \\
\hline & \\
\hline
\end{tabular}




\section{TABLE OF CONTENTS}

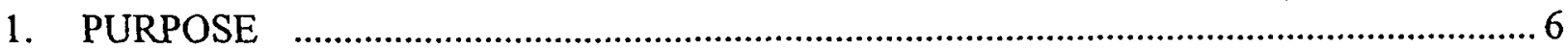

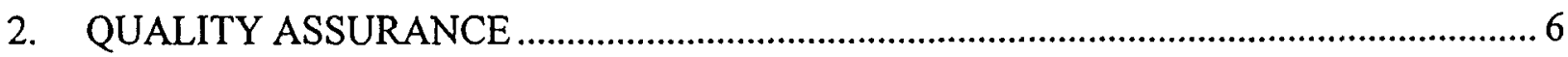

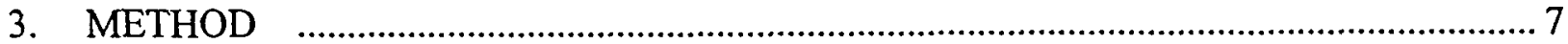

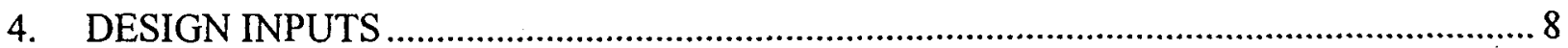

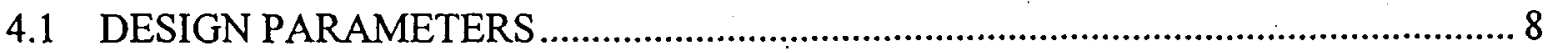

4.2 CRITERIA

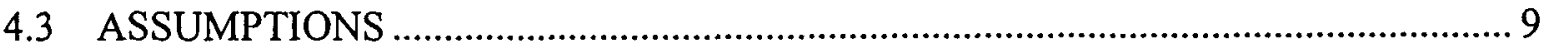

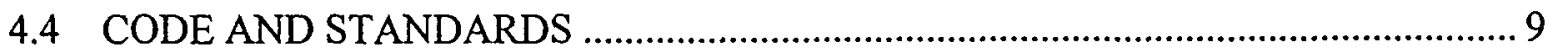

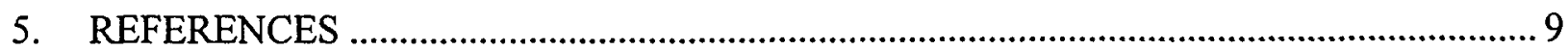

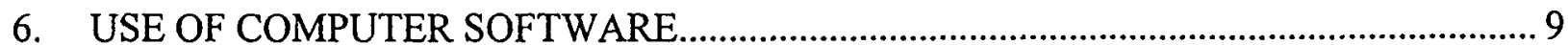

7. SELECTION OF CANDIDATE EQUIPMENT ……...................................................

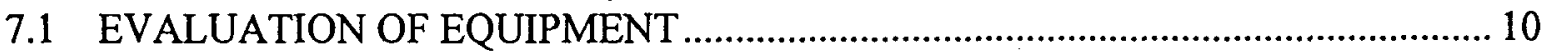

7.2 DEVELOPMENT TEST FUNCTIONS ....................................................... 17

7.2.1 DC Decontamination Manipulator, PU-EM-112; DC Decontamination/ Inspection Manipulator, PD-EM-101; and DC Decontamination Tool,

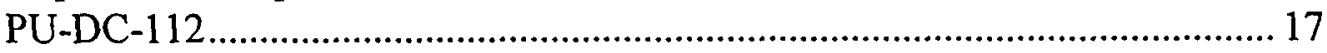

7.2.2 DC Inner Lid Sealing Device, PU-DE-119 ............................................... 17

7.2.3 Cask Preparation Manipulator and Special Tooling, PU-EM-110 ………........ 17

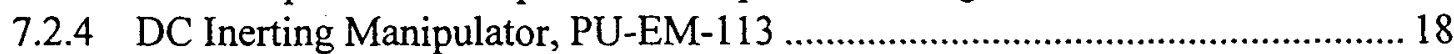

7.2.5 Wet Assembly Transfer Machine, PU-MA-112, and Wet Assembly Lifting Grapples, PU-FX-113 ................................................................................. 18

7.2.6 Dry Assembly Transfer Machine, PU-MA-115; Dry Assembly Lifting Grapples, PU-FX-111; and DC Lid Lifting Device, PU-DE-116 .................... 18

7.2.7 Large DPC Lid Severing Tool, PU-ME-110, and Small DPC Lid Severing

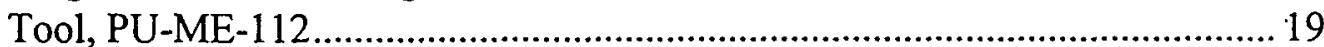

7.2.8 Waste Package Remediation Cell Cutting Machine, PR-ME-100 …………..... 19

7.2.9 DC Welding Station Jib Crane, PD-CN-102 ……............................................ 19

7.2.10 DC Horizontal Transfer Cart, PD-CR-100 ………........................................ 19

7.2.11 DC Lifting Collar, PD-FX-119, and DC Base Collar, PD-FX-120 …............ 20

7.2.12 DC Horizontal Lifting Machine, PD-MA-100 ……...................................... 20

7.2.13 DC Welding/Inspection Machine, PD-ME-101 …….................................. 20

7.2.14 Cask Transfer Cart, PU-CR-110; Incline Transfer Canal Cart, PU-CR-111; DC Transfer Cart, PU-CR-112; Cross-Line Transfer Canal Cart, PU-CR-113; Cask Transfer Cart, PC-CR-110; DC Transfer Cart, PC-CR-111; WPRC Transfer Cart, PC-CR-100; and Empty DC Transfer Cart, PD-CR-101 ......... 21

7.3 DEVELOPMENT TEST STRATEGIES ............................................................ 21

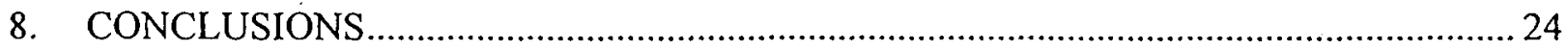

Attachment I: MGR Surface Waste Handling System Equipment List 


\section{FIGURES}

Figure 7-1. Selection of Equipment for Development Testing ................................................. 10

Figure 7-2. MGR Program Schedule …………………….................................................. 23

\section{TABLES}

Table 2-1. QA Classification Assignments..........................................................................

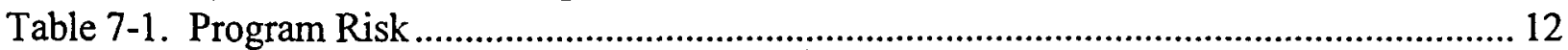

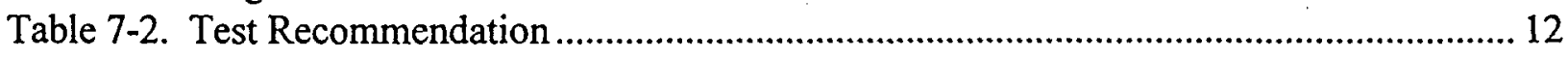

Table 7-3. Development Testing Assessment.......................................................................... 13 


\section{ACRONYMS}

$\begin{array}{ll}\text { CCTV } & \text { closed-circuit television } \\ \text { CFR } & \text { Code of Federal Regulations } \\ \text { CRWMS } & \text { Civilian Radioactive Waste Management System } \\ \text { DC } & \text { disposal container } \\ \text { DOE } & \text { (U.S.) Department of Energy } \\ \text { DPC } & \text { dual-purpose canister } \\ \text { LA } & \text { License Application } \\ \text { LLW } & \text { low-level waste } \\ \text { M\&O } & \text { Management \& Operating (Contractor) } \\ \text { MGDS } & \text { Mined Geologic Disposal System } \\ \text { MGR } & \text { Monitored Geologic Repository } \\ \text { MRS } & \text { Monitored Retrievable Storage } \\ \text { NRC } & \text { Nuclear Regulatory Commission } \\ \text { QA } & \text { Quality Assurance } \\ \text { QAP } & \text { Quality Administrative Procedure } \\ \text { QARD } & \text { Quality Assurance Requirements and Description } \\ \text { RDRD } & \text { Repository Design Requirements Document } \\ \text { SNL } & \text { Sandia National Laboratory } \\ \text { T\&EP } & \text { Test and Evaluation Plan } \\ \text { VA } & \text { Viability Assessment } \\ \text { WHB } & \text { Waste Handling Building } \\ \text { WP } & \text { waste package } \\ \text { WPRC } & \text { Waste Package Remediation Cell } \\ \text { YMP } & \text { Yucca Mountain Project }\end{array}$




\section{PURPOSE}

The purpose of this study is to identify candidate Monitored Geologic Repository (MGR) surface waste handling equipment for development testing. This study will also identify strategies for performing the development tests. Development testing shall be implemented to support detail design and reduce design risks. Development testing shall be conducted to confirm design concepts, evaluate alternative design concepts, show the availability of needed technology, and provide design documentation. The candidate equipment will be selected from MGR surface waste handling equipment that is the responsibility of the Management and Operating Contractor $(\mathrm{M} \& O)$ Surface Design Department. The equipment identified in this study is based on Viability Assessment (VA) design.

The Monitored Geologic Repository Test and Evaluation Plan (MGR T\&EP), Reference 5.1, was used as a basis for this study. The MGR T\&EP reflects the extent of test planning and analysis that can be conducted, given the current status of the MGR requirements and latest VA design information. The MGR T\&EP supports the appropriate sections in the license application (LA) in accordance with 10 CFR 60.21(c)(14).

The MGR T\&EP describes the following test activities: site characterization to confirm, by test and analysis, the suitability of the Yucca Mountain site for housing a geologic repository; development testing to investigate and document design concepts to reduce risk; qualification testing to verify equipment compliance with design requirements, specifications, and regulatory requirements; system testing to validate compliance with MGR requirements, which include the receipt, handling, retrieval, and disposal of waste; periodic performance testing to verify preclosure requirements and to demonstrate safe and reliable MGR operation; and performance confirmation modeling, testing, and analysis to verify adherence to postclosure regulatory requirements.

Development test activities can be planned and conducted by the appropriate design organization as part of the design process. The scope of this study, therefore, will address only surface development testing activities that will be performed prior to detail design and procurement of the MGR surface waste handling equipment. Testing to support development of additional MGR surface equipment and operations, such as cooling of shipping casks and dualpurpose canisters (DPCs) prior to pool entry, decontamination of disposal containers (DCs), and recovery systems for various equipment, is not addressed in this study. These equipment items/systems were not developed for VA and are not currently identified as specific MGR surface waste handling equipment.

\section{QUALITY ASSURANCE}

An activity evaluation, Waste Handling Systems (Work Package 12462400M4) (Reference 5.2) has been performed in accordance with QAP-2-0, Conduct of Activities. Based on this evaluation, it has been determined that this analysis is subject to the requirements of the Quality 
Assurance Requirements and Description (QARD) (Reference 5.3). In addition, review of the classification of permanent items described in Classification of the Preliminary MGDS Repository Design (Reference 5.4), prepared in accordance with QAP-2-3, Classification of Permanent Items, has been performed. It is assumed that the listed equipment within the Waste Handling Equipment Development Tests and Evaluation Study will carry the "Q" classification (Assumption 4.3.1). Table 2-1 lists the systems and presents the QA classification assignments.

Table 2-1. QA Classification Assignments

\begin{tabular}{|l|l|l|}
\hline System Number & System & QA Classification $^{\text {' }}$ \\
\hline SU02 & $\begin{array}{l}\text { Waste Handling Building (WHB) } \\
\text { System }\end{array}$ & $\begin{array}{l}\text { QA-1, QA-3, QA-4, QA-5, } \\
\text { QA-6, QA-7 }\end{array}$ \\
\hline SU08 & $\begin{array}{l}\text { Carrier Preparation Building } \\
\text { Material Handling System }\end{array}$ & QA-5 \\
\hline SU09 & Carrier/Cask Handling System & QA-1, QA-3, QA-5, QA-7 \\
\hline SU10 & Assembly Transfer System & $\begin{array}{l}\text { QA-1, QA-2, QA-3, QA-5, } \\
\text { QA-7 }\end{array}$ \\
\hline SU11 & Canister Transfer System & QA-1, QA-7 \\
\hline SU12 & Waste Package (WP) Remediation & $\begin{array}{l}\text { QA-1, QA-2, QA-3, QA-5, } \\
\text { QA-7 }\end{array}$ \\
\hline SU13 & System & $\begin{array}{l}\text { QA-1, QA-2, QA-3, QA-5, } \\
\text { QA-7 }\end{array}$ \\
\hline SU51 & Disposal Container (DC) Handling & Son-Q \\
\hline
\end{tabular}

Based on Table 2-1, items addressed in this study are to be considered " $Q$ " items, and, as specified in NLP-3-18, this study is documented as being subject to QA controls.

\section{METHOD}

The methods used in this study consist of the following:

- Identification of MGR surface waste handling equipment that is the responsibility of the M\&O Surface Design Department.

- Development of screening criteria to determine when development testing will be required to support MGR equipment detail design. The equipment design risk is considered high if the design potentially cannot be licensed, constructed, or operated safely, reliably, or at sufficient speed to meet MGR waste handling throughput.

\footnotetext{
I QAP-2-3 REV $09(07 / 20 / 98)$ retracted the use of Classifications 6 and 7 . However, Classification of the Preliminary MGDS Repository Design has not yet been revised to reflect the changes. Therefore, classifications are as listed in QAP-2-3 REV 08.
} 
- Review of the list of MGR surface waste handling equipment (See Table I-1, Attachment I) to identify candidate equipment for developing testing. If one or more of the evaluation criteria identified in Section 7.1.1 applies to an equipment item, it is identified as a high-risk item requiring development testing.

- Further evaluation of the candidate equipment in the areas of probability, consequence, cost, and program risk; recommendation of a final list of candidate equipment for development testing.

- Identification of development test functions for each candidate equipment item.

- Discussion of the strategy for accomplishing the testing (i.e., when and where) and identification of testing issues (i.e., consequences of not testing, cost minimization, testing schedules, test locations, etc.).

\section{DESIGN INPUTS}

\subsection{DESIGN PARAMETERS}

4.1.1 LA requires an identification of those surface repository equipment items that require research and development to confirm the adequacy of design (10CFR $60.21(\mathrm{c})(14)$.

4.1.2 A list of MGR surface equipment is provided in the Interoffice Correspondence, S.J. Meyers to R.E. Howell, Waste Handling Systems Equipment List, North Portal Repository, Surface Facility (LV.SD.SJM.8/98.088, August 19, 1998).

\subsection{CRITERIA}

The following criteria, which are applicable to this report, are found in the Mined Geologic Disposal System Requirements Document (MGDS-RD) (Reference 5.5).

4.2.1 Methods to be used to verify the conformance of the MGR equipment items with their design requirements are:

- Demonstration of the performance of the function of the system or item in or near its operational environment (prototype test) (MGDS-RD 4.2.c)

- Test of a product to verify design compliance with requirements and specification in a laboratory or in the field (in situ) (MGDS-RD 4.2.d) 


\subsection{ASSUMPTIONS}

4.3.1 The equipment items for the systems shown in Table 2-1 were assigned a QA classification based on the QA classifications identified for similar equipment in the Classification of the Preliminary MGDS Repository Design (Reference 5.4).

\subsection{CODE AND STANDARDS}

The following codes and standards are used in this study: 4.4.1 10CFR 60. Disposal of High-Level Radioactive Waste in Geological
Repositories. Section 60.21(c)(14).

\section{REFERENCES}

5.1 CRWMS (Civilian Radioactive Waste Management System) M\&O 1998a. Monitored Geologic Repository Test and Evaluation Plan, B00000000-01717-5705-00058, REV 02. Las Vegas, Nevada: Author. MOL.19980729.0006.

5.2 CRWMS M\&O 1998b. Activity Evaluation, Waste Handling Systems Design (Work Package 12462400M4). Las Vegas, Nevada: Author. MOL.19980122.0403.

5.3 DOE 1998a. Quality Assurance Requirements and Description (QARD) for the Civilian Radioactive Waste Management Program. DOE/RW-0333P REV 08. Washington, DC: U.S. Department of Energy (DOE) Office of Civilian Radioactive Waste Management. MOL.19980601.0022.

5.4 CRWMS M\&O 1997. Classification of the Preliminary MGDS Repository Design, B00000000-01717-0200-00134 REV 00. Las Vegas, Nevada: Author. MOL.19980211.1192.

5.5 YMP 1998. Mined Geological Disposal System Requirements, YMP/CM-0025, Revision 3. Las Vegas, Nevada: Author. MOL.19980520.1022.

\section{USE OF COMPUTER SOFTWARE}

No engineering or scientific software was used for this study. 


\section{SELECTION OF CANDIDATE EQUIPMENT}

Based on the current MGR conceptual design configuration for the VA, all surface waste handling equipment has been identified that is the responsibility of the M\&O Surface Design Department. During the procurement and construction design phase, detail designs for this equipment will be developed. In order to support detail design and reduce risk, some of the surface equipment may require development testing. Development testing will be used to support equipment design activities by confirming design concepts, identifying design improvements, evaluating alternative design concepts, and verifying the availability of needed technology. Development testing could involve modeling, prototype build, and mock-up support. This study consists of the selection of candidate equipment items for development testing, identification of test functions, and development of strategies for accomplishing the testing. The candidate equipment selection process is presented in Figure 7-1 and discussed in the following sections.

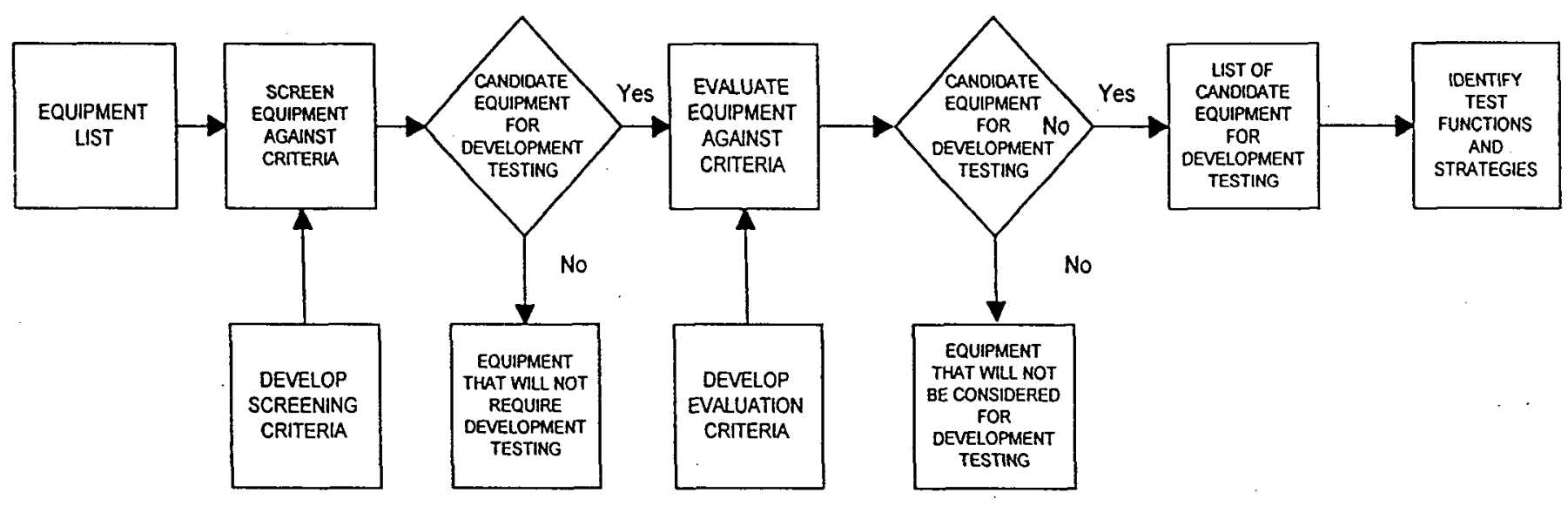

Figure 7-1. Selection of Equipment for Development Testing

\subsection{EVALUATION OF EQUIPMENT}

The basic criterion for performing development tests is that the costs of conducting these tests will be lower than the program risk resulting from not conducting the tests. The program risk pertains to the ability of the MGR to be licensed, constructed, and operated safely, reliably, and with sufficient capacity (throughput). Risk is the probability that the design will not work with respect to the consequence of not working. The primary indicator for probability is design precedent. Equipment that has been successfully used in the past have a low probability of not working as designed. Consideration needs to be given to maturity of the technology, the working environment (e.g., high radiation area and inaccessible hot cells), as well as the service 
demands (e.g., high reliability, continuous operation). Consequence is characterized by the costs, safety (ALARA, industrial, etc. ), schedule delays, and political impacts resulting from correcting the design/facilities, if a design problem occurs. Consequence could also be characterized by reduced performance if the design problem is not corrected.

The following screening criteria were developed for the purpose of evaluating MGR surface waste handling equipment for potential development testing:

a. First-of-a-kind Design: Equipment employs a new design that has not been used in the past for similar handling operations in a DOE/NRC nuclear facility or commercial nonnuclear facility.

b. Unusual Performance Requirements: Equipment employs a proven design but must perform in unusual or unproven application (e.g., high-lift load, travel rate, quantity, etc.)

c. No Licensing Precedent: Equipment has not been used in an NRC-licensed facility and development testing may be needed to support a safety case.

d. New or Extreme Environment: Equipment is used in an environment that is new or exceeds prior use (e.g., underwater, high temperature, high radiation level, inaccessible cell location, etc.).

e. Perceived Requirement for Testing: Program participants or oversight groups have expressed concern over operational risks associated with the design of specific equipment.

The MGR surface waste handling systems equipment list was surveyed against the screening criteria. If one or more of the screening criteria applies to an equipment item, it is considered a candidate for development testing. If no screening criteria applies to an equipment item, it is expected to function as designed without development testing. The results are provided in Table I-1, Attachment I.

The candidate equipment was further evaluated and qualitatively scored in the areas of probability of failure and consequence of failure. The probability of failure of a specific equipment item is identified as the degree to which one or more of the screening criteria applies to the item (e.g., completely new design approach vs. slightly unusual operating environment). Based on this evaluation, the probability of failure is identified as high (H), medium (M), or low (L).

The consequence of failure is also identified as high $(\mathrm{H})$, medium $(\mathrm{M})$, or low (L). Failure of an equipment item that would result in a high cost to repair/replace, would affect safety (ALARA) to repair/replace, would result in substantial schedule delays, or would require extensive correction of the design/facilities, is considered as having a high consequence of failure. Failure 
of an equipment. item that would involve a minor repair, minimal safety concerns, minimal schedule delays, or minor design/facility corrections is considered as having a low consequence of failure. A medium consequence of failure equipment item would fall somewhere in between.

Alternatively, consequence of failure may be a decrease in surface waste handling operations performance when a repair is not performed.

The program risk, identified as high $(\mathrm{H})$, medium $(\mathrm{M})$, or low $(\mathrm{L})$, was developed based on the scoring combinations of "probability of failure" and "consequence of failure." Table 7-1 shows the selected combinations.

Table 7-1. Program Risk

\begin{tabular}{|l|l|l|l|l|l|l|l|l|l|}
\hline Probability of Failure & H & M & L & H & M & L & H & M & L \\
\hline Consequence of Failure & H & H & H & M & M & M & L & L & L \\
\hline Program Risk & H & H & M & H & M & M & M & M & L \\
\hline
\end{tabular}

Test cost is also identified as high $(\mathrm{H})$, medium $(\mathrm{M})$, and low (L) and is associated with overall cost of the development test, including test facility, test hardware, control system, data system, equipment being tested, and work hours. As an example, a high cost test would include full-size prototype equipment, full-size mock-ups, a large test facility, possibly including a pool, a fully automated control system, and an extensive data collection system. A low cost test would probably involve component testing in a small shop or lab. A medium cost test would fall somewhere in between.

The program risk is then compared with the test cost to determine if a development test is recommended. The recommendation to test is identified as yes $(\mathrm{Y})$, no $(\mathrm{N})$, or possibly $(\mathrm{P})$. A designation of "possibly" indicates that a particular equipment item is not identified as a candidate for development testing at this time but may be recommended during later stages of MGR design as the design configurations mature. Table 7-2 shows the relationship among risk, cost, and test recommendation.

Table 7-2. Test Recommendation

\begin{tabular}{|l|l|l|l|l|l|l|l|l|l|}
\hline Program Risk & H & M & L & H & M & L & H & M & L \\
\hline Test Cost & H & H & H & M & M & M & L & L & L \\
\hline Test Recommendation & Y & N & N & Y & P & N & Y & Y & P \\
\hline
\end{tabular}

Table 7-3 presents the results of an evaluation of each equipment item identified as a candidate for development testing in Table I-1. The results present the recommendation as to which equipment items should be development tested. The specific design concerns associated with each equipment item are also presented. 
Table 7-3. Development Testing Assessment

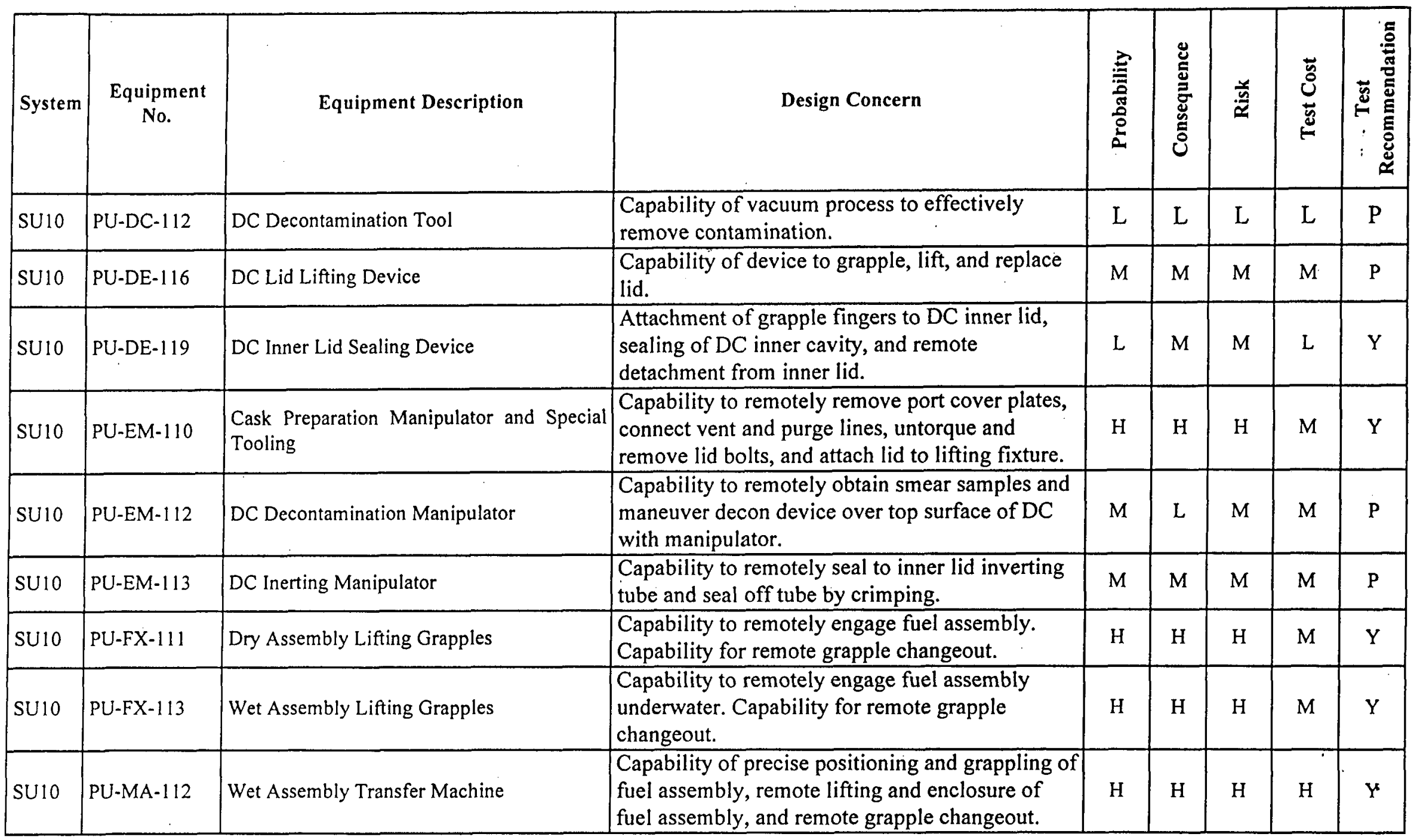




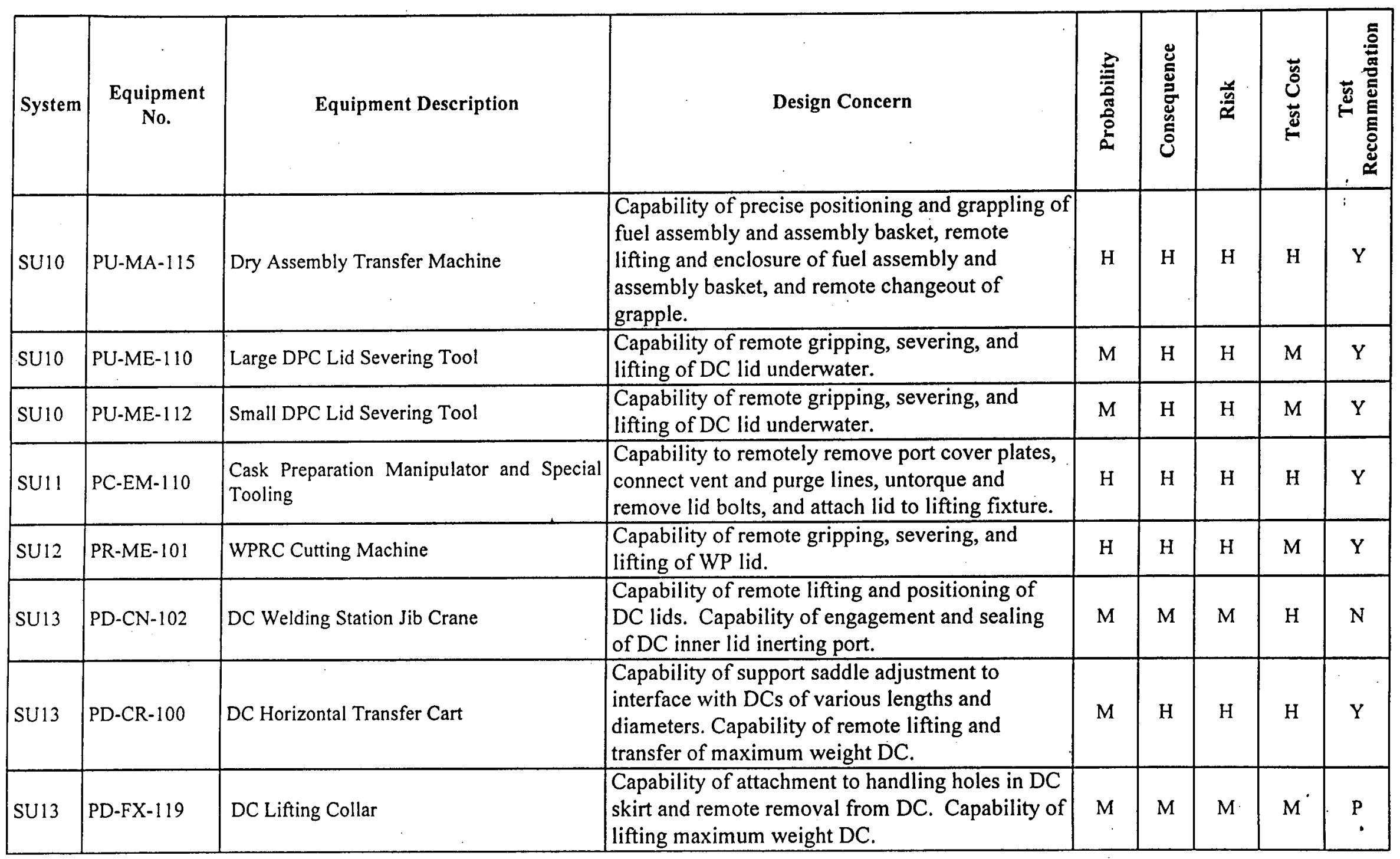




\begin{tabular}{|c|c|c|c|c|c|c|c|c|}
\hline System & $\begin{array}{c}\text { Equipment } \\
\text { No. }\end{array}$ & Equipment Description & Design Concern & $\frac{2}{2}$ & 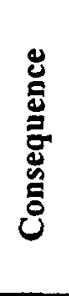 & $\frac{y}{a}$ & 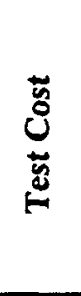 & 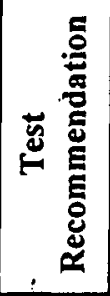 \\
\hline SU13 & PD-FX-120 & DC Base Collar & $\begin{array}{l}\text { Capability of attachment to handling holes in DC } \\
\text { skirt and remote removal from DC. Capability of } \\
\text { supporting maximum weight DC. Capability of } \\
\text { being engaged by cart to prevent DC turnover. }\end{array}$ & $\mathrm{M}$ & M & M & M & $P$ \\
\hline SU13 & PD-MA-100 & DC Horizontal Lifting Machine & $\begin{array}{l}\text { Capability of remote lifting of various length } \\
\text { DCs in a horizontal position by means of the DC } \\
\text { skirts. }\end{array}$ & M & $M$ & M & $\mathrm{H}$ & $N$ \\
\hline SU10 & PU-CR-110 & Cask Transfer Cart & $\begin{array}{l}\text { Capability of supporting and gripping DCs in a } \\
\text { vertical position, gripping rails to prevent DC } \\
\text { turnover, and supporting and remotely } \\
\text { transferring maximum weight DCs. }\end{array}$ & L & $\mathrm{L}$ & $\mathrm{L}$ & $\mathrm{H}$ & $N$ \\
\hline SU10 & PU-CR-111 & Incline Transfer Canal Cart & $\begin{array}{l}\text { Capability of supporting and gripping DCs in a } \\
\text { vertical position, gripping rails to prevent DC } \\
\text { turnover, and supporting and remotely } \\
\text { transferring maximum weight DCs. }\end{array}$ & $\mathrm{L}$ & $\mathrm{L}$ & $\mathrm{L}$ & $\mathrm{H}$ & $\mathrm{N}$ \\
\hline SU10 & PU-CR-112 & DC Transfer Cart & $\begin{array}{l}\text { Capability of supporting and gripping DCs in a } \\
\text { vertical position, gripping rails to prevent DC } \\
\text { turnover, and supporting and remotely } \\
\text { transferring maximum weight DCs. }\end{array}$ & $\mathrm{L}$ & $\mathrm{L}$ & $\mathrm{L}$ & $\mathrm{H}$ & $\mathrm{N}$ \\
\hline SU10 & PU-CR-113 & Cross-line Transfer Canal Cart & $\begin{array}{l}\text { Capability of supporting and gripping DCs in a } \\
\text { vertical position, gripping rails to prevent DC } \\
\text { turnover, and supporting and remotely } \\
\text { transferring maximum weight DCs. }\end{array}$ & $\mathrm{L}$ & $\mathrm{L}$ & $\mathrm{L}$ & $\mathrm{H}$ & $\mathrm{N}$ \\
\hline
\end{tabular}




\begin{tabular}{|c|c|c|c|c|c|c|c|c|}
\hline System & $\begin{array}{c}\text { Equipment } \\
\text { No. }\end{array}$ & Equipment Description & Design Concern & 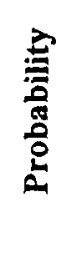 & 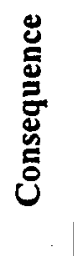 & $\frac{1}{x}$ & 苍 & 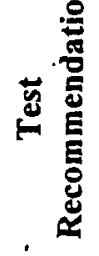 \\
\hline SU11 & PC-CR-110 & Cask Transfer Cart & $\begin{array}{l}\text { Capability of supporting and gripping DCs in a } \\
\text { vertical position, gripping rails to prevent DC } \\
\text { turnover, and supporting and remotely } \\
\text { transferring maximum weight DCs. }\end{array}$ & $\mathrm{L}$ & L & L & $\mathrm{H}$ & $\mathrm{N}$ \\
\hline SU11 & PC-CR-111 & DC Transfer Cart & $\begin{array}{l}\text { Capability of supporting and gripping DCs in a } \\
\text { vertical position, gripping rails to prevent DC } \\
\text { turnover, and supporting and remotely } \\
\text { transferring maximum weight DCs. }\end{array}$ & $\mathrm{L}$ & $\mathrm{L}$ & $\mathrm{L}$ & $\mathrm{H}$ & $N$ \\
\hline SU 12 & PC-CR-100 & WPRC Transfer Cart & $\begin{array}{l}\text { Capability of supporting and gripping DCs in a } \\
\text { vertical position, gripping rails to prevent DC } \\
\text { turnover, and supporting and remotely } \\
\text { transferring maximum weight DCs. }\end{array}$ & $\mathrm{L}$ & L & L & $\mathrm{H}$ & $N$ \\
\hline
\end{tabular}




\subsection{DEVELOPMENT TEST FUNCTIONS}

The following section presents a discussion of the development test functions recommended for the MGR surface equipment identified as candidates for development testing in Table 7-3. If the current VA MGR design indicates that two or more equipment items must operate as a unit to perform the surface waste handling operations, the following discussions address the requirement to test these equipment items as a unit. In some instances, only individual components of the equipment items require development testing.

\subsubsection{Decontamination Manipulator, PU-EM-112; DC Decontamination/ Inspection Manipulator, PD-EM-101; and DC Decontamination Tool, PU- DC-112}

The initial test shall consist of removing simulated contamination from mock-up surfaces to determine if the contamination can be adequately removed. The surfaces shall mock up the surfaces expected on a DC.

The second test shall consist of obtaining a smear sample from a surface using the manipulator to determine if an electro-mechanical manipulator can be controlled accurately enough to obtain a sample without damaging the smear pad. In addition, the manipulator shall be demonstrated to determine if the smear sample can be remotely placed in a transfer device for evaluation.

Finally, a test shall be performed to determine if the manipulator can effectively maneuver over the surface area of a simulated DC in both an automatic programmed mode and a remote manual mode.

All viewing shall be by remote closed-circuit television (CCTV).

\subsubsection{Inner Lid Sealing Device, PU-DE-119}

A DC inner lid sealing device will be attached to a mock-up of the DC inner lid and the sealing device and lid installed as a unit in the open top of a DC mock-up. This test will determine if the sealing device will mate adequately with the $\mathrm{DC}$ to effectively provide a sealed closure for the inner cavity of the DC. A hex drive on the sealing device will be operated to demonstrate that the sealing device can be remotely detached from the DC inner lid, with the inner lid remaining in place in the simulated DC.

\subsubsection{Cask Preparation Manipulator and Special Tooling, PU-EM-110}

A cask preparation manipulator and a mock-up of the top surface of a cask shall be used to develop and demonstrate special tools for remote cask preparation activities. Cask preparation activities include port cover plate removal, vent/purge line connection, lid 
bolt untorquing and removal, and lid lifting fixture attachment. All viewing shall be by remote CCTV. Cask preparation operations must be preformed remotely to achieve ALARA limits, which are unprecedented in the nuclear industry due to the MGR throughput rates. Sandia National Laboratory (SNL) has studied remote cask preparation for the Monitored Retrievable Storage (MRS) facility. The results can be reviewed for development of this system.

\subsubsection{Inerting Manipulator, PU-EM-113}

The inerting head portion of the DC inerting manipulator and a simulated DC inner lid inerting port shall be used to demonstrate that the inerting head can be remotely sealed to the inerting tube and then be capable of closing off the end of the tube by crimping. Research and development of alternative inerting methods may also be required.

\subsubsection{Wet Assembly Transfer Machine, PU-MA-112, and Wet Assembly Lifting Grapples, PU-FX-113}

A prototype wet assembly transfer machine, equipped with a variety of wet assembly grapples, shall be developed and demonstrated using simulated fuel assemblies, a cask mock-up, an assembly basket mock-up, and a fuel pool mock-up. The development testing shall demonstrate remote changeout of fuel assembly grapples; precise transfer machine positioning over fuel assembly guide tubes; underwater orientation of the grapple system ( $\mathrm{x}-\mathrm{y}$ and rotational); grappling of various fuel assembly configurations; withdrawal of fuel assemblies into the transfer machine enclosure; removal of a fuel assembly from a cask; placement of the fuel assembly into an assembly basket; and gripping and transfer of a loaded fuel assembly basket. Viewing shall be by personnel positioned on the assembly transfer machine bridge and underwater CCTV.

Development testing of the wet assembly transfer machine and the dry assembly transfer machine addressed in Section 7.2.6 may be performed using one basic machine subjected to dry testing and wet testing.

\subsubsection{Dry Assembly Transfer Machine, PU-MA-115; Dry Assembly Lifting Grapples, PU-FX-111; and DC Lid Lifting Device, PU-DE-116}

A prototype dry assembly transfer machine, equipped with a variety of dry assembly grapples, shall be developed and demonstrated using simulated fuel assemblies, an assembly basket mock-up, a DC mock-up, a drying vessel mock-up, and a prototype DC inner lid sealing device. The development testing shall demonstrate remote changeout of fuel assembly grapples, precise transfer machine positioning over fuel assembly guide tubes, orientation of the grapple system ( $x-y$ and rotational) and grappling of various fuel assembly configurations, withdrawal of fuel assemblies into the transfer machine enclosure, removal of a fuel assembly from a basket, placement and removal of a fuel assembly from the drying vessel, placement of the fuel assembly into a DC fuel assembly 
guide tube, grappling and transfer of a loaded assembly basket, and grappling and handling of the DC inner lid sealing device. Viewing shall be by remote CCTV:

\subsubsection{Large DPC Lid Severing Tool, PU-ME-110, and Small DPC Lid Severing Tool, PU-ME-112}

A prototype large or small dual-purpose canister (DPC) lid severing tool shall be developed and demonstrated using a simulated upper section of a large/small DPC and a pool or tank. The development test shall demonstrate remote underwater engagement of the simulated DPC, severing of the upper DPC lid section, and lifting of the severed section out of the water. The test shall also demonstrate underwater vacuuming and removal of the cutting chips. Alternate cutting technologies can also be developed and demonstrated during this development test effort. Viewing shall be by personnel positioned over the water surface or by CCTV as required.

\subsubsection{Waste Package Remediation Cell Cutting Machine, PR-ME-100}

A prototype waste package remediation cell (WPRC) cutting machine shall be developed and demonstrated using a simulated upper section of a waste package (WP). The development test shall demonstrate remote engagement of the WP upper lid, severing of the lid from the WP body, and withdrawal of the lid from the WP. The severing process shall also be demonstrated on the WP inner lid. The test shall also demonstrate removal of the cutting chips. Alternative cutting technologies can also be developed and demonstrated during this development test effort. Viewing shall be by remote CCTV.

\subsubsection{Welding Station Jib Crane, PD-CN-102}

A prototype DC welding station jib crane shall be developed and demonstrated using a simulated DC inner lid sealing device and a simulated DC outer lid. The development test shall demonstrate precise remote orientation of the jib crane grapple and inerting head using the rotation of the jib boom, linear travel of the jib crane trolleys, and vertical travel of the jib crane telescoping masts. The test shall also demonstrate engagement and lifting of the sealing device and DC lid using the grapple, and remote engagement of the sealing device inerting port by the jib crane inerting head. Viewing shall be by remote CCTV. The jib inerting head technology will be developed and demonstrated during the DC inerting manipulator development testing (Section 7.2.4).

\subsubsection{Horizontal Transfer Cart, PD-CR-100}

A prototype DC horizontal transfer cart shall be developed and demonstrated using simulated DCs of maximum and minimum lengths, maximum weights, and equipped with trunnions; a simulated DC lifting yoke; a simulated DC tilting fixture; and a short set of rails. The development testing shall simulate $\mathrm{DC}$ handling in the vertical mode, placement of the DC lower trunnions into the tilting fixture, rotation of the DCs from 
vertical to horizontal, and the ability of the transfer cart adjustable saddles to be moved laterally and vertically to engage and support the various length DCs as they are rotated to the horizontal position on the simulated tilting fixture. The testing shall also demonstrate the ability of the transfer cart to elevate the DC in the horizontal orientation such that the DC trunnions disengage from the tilting fixture and withdraw the supported $\mathrm{DC}$ away from the tilting fixture on the set of rails. Remote operation and viewing shall be by CCTV.

\subsubsection{Lifting Collar, PD-FX-119, and DC Base Collar, PD-FX-120}

A prototype DC lifting collar and a prototype DC base collar shall be attached manually (non-remote) to the upper and lower ends of a simulated DC to demonstrate that the collars will adequately engage the DC handling skirts and that three locking pins on each collar can be inserted into handling holes in the skirts using an impact wrench or a similar tool. A weight representing the heaviest DC shall be applied to the simulated DC segment and the segment lifted by means of a simulated DC lifting yoke engaging the lifting collar trunnions. This test will demonstrate that the DC weight can be adequately supported by the collar, locking pin, and trunnion configurations. A load shall be applied to the base collar to simulate handling loads when the DC is supported vertically by a transfer cart and the base collar trunnions are restrained by cart locking devices. The test will demonstrate that the collar can adequately resist the handling loads. The collar locking pins will then be retracted by the impact wrench and the collars removed from the DC by means of the collar lifting bail to demonstrate remote removal of the collars from the DC.

\subsubsection{Horizontal Lifting Machine, PD-MA-100}

A development test shall be performed using a prototype DC horizontal lifting machine and simulated DCs, representing the maximum DC weight and maximum and minimum $\mathrm{DC}$ lengths. The test shall demonstrate that the horizontal lifting machine configuration can be remotely adjusted for DC length and can remotely engage the DC handling skirts, lift the DC, and suspend the DC, via the skirts, for several hours. Viewing shall be by window and remote CCTV.

\subsubsection{Welding/Inspection Machine, PD-ME-101}

A DC welding/inspection machine prototype research and development program is currently being performed by the Waste Package Department. 


\subsubsection{Cask Transfer Cart, PU-CR-110; Incline Transfer Canal Cart, PU-CR-111; DC Transfer Cart, PU-CR-112; Cross-Line Transfer Canal Cart, PU-CR- 113; Cask Transfer Cart, PC-CR-110; DC Transfer Cart, PC-CR-111; WPRC Transfer Cart, PC-CR-100; and Empty DC Transfer Cart, PD-CR- 101}

A prototype cart shall be developed and demonstrated using simulated shipping casks, DCs, and assembly baskets of maximum lengths and maximum weights. The development testing shall demonstrate 1) the cart's support and restraint of the cask, DCs, and baskets and 2) remote operation to move and position the loaded cart on a rail system.

\subsection{DEVELOPMENT TEST STRATEGIES}

The MGR surface waste handling equipment identified as candidates for development testing in Section 7.1 were selected based on the screening and evaluation criteria. Introducing new or unproven technical approaches into the detailed design process presents risks to developing equipment that can be licensed, constructed, and operated safely, reliably, and with sufficient capacity (throughput). In order to confirm design concepts and integrate this information into the detail designs, development testing must be performed early in the MGR surface waste handling equipment development phase. If the results of components and materials lab testing needs to be integrated into the full scale prototype tests, lab tests will have to be performed before or during prototype testing. As a result, all component testing, equipment testing, and system testing must be performed after LA but prior to final detail design and procurement.

Potential locations for small component and material testing (lab testing) include subcontractor shops, vendor facilities, and test laboratories. Potential locations for full scale equipment and system prototype testing include major fabricator or vendor facilities, existing nuclear facilities, DOE facilities at national laboratory sites, and MGR test and evaluation facilities.

Figure 7-2 presents a preliminary schedule that indicates when the development testing must be performed in order to provide information to support MGR waste handling equipment detail design and procurement.

In order to reduce development test costs, a number of individual equipment tests could be performed concurrently. The tests could share a common facility, cranes, manipulators, pools, simulated fuel assemblies, baskets, DC mock-ups, test hardware, utilities, and data collection systems. The following are suggested groups of equipment that could be development tested concurrently (See Section 7.2). 
Equipment items to be tested currently

$\underline{\text { See Section }}$

Cask Preparation Manipulator and Special

7.2 .3

1 Tooling, PU-EM-110

DC Inerting Manipulator, PU-EM-113

2 Wet Assembly Transfer Machine, PU-MA-112

7.2 .5

Dry Assembly Transfer Machine, PU-MA-115

7.2 .6

Large DPC Lid Severing Tool, PU-ME-110 and

7.2.7

3 Small DPC Lid Severing Tool, PU-ME-112

Waste Package Remediation Cell Cutting

Machine, PR-ME-100

7.2 .8

DC Horizontal Transfer Cart, PD-CR-100

7.2 .10

4 DC Lifting Collar, PD-FX-119 and DC Base

7.2 .11

Collar, PD-FX-120

DC Horizontal Lifting Machine, PD-MA-100

7.2 .12 


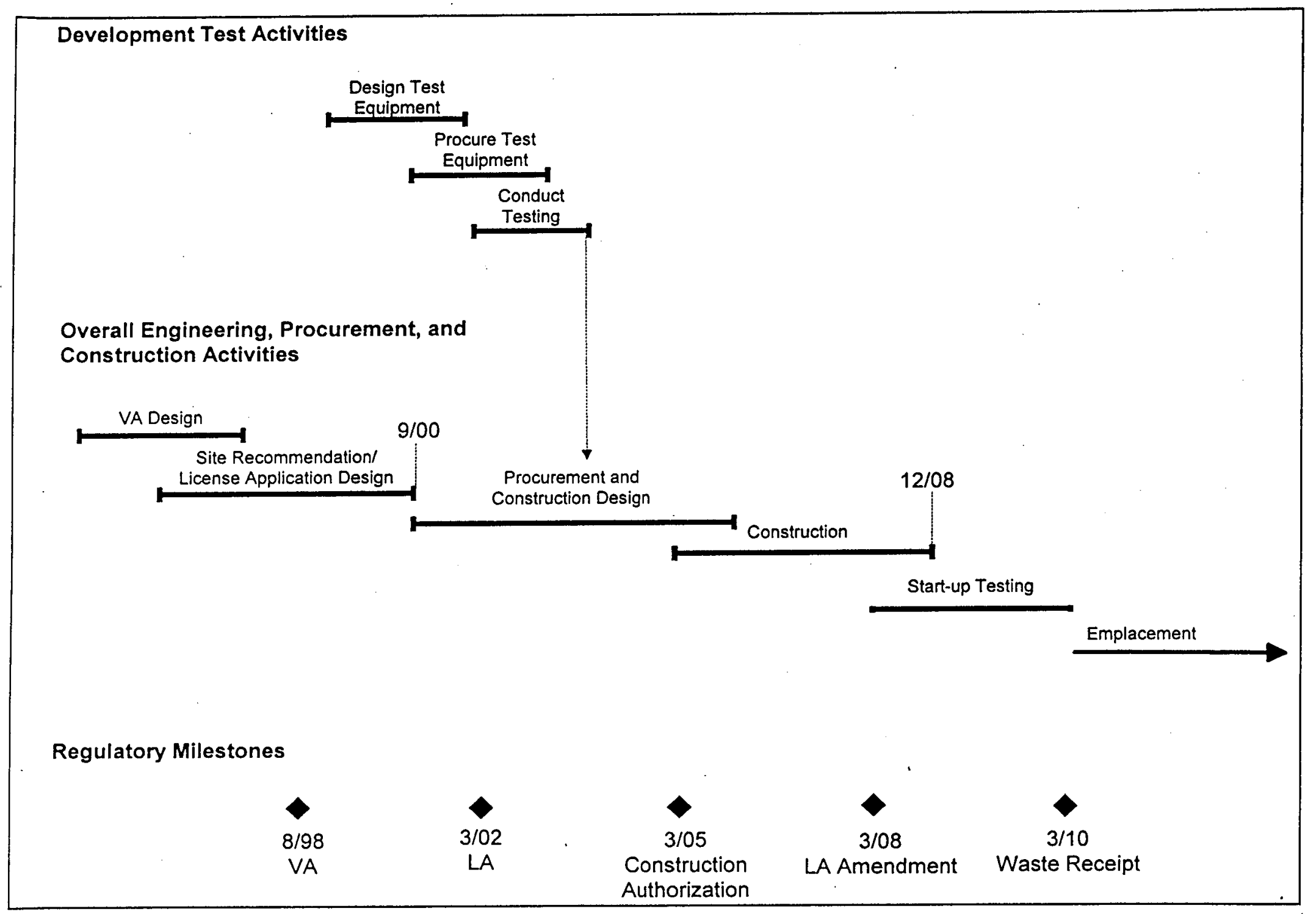

Figure 7-2. MGR Program Schedule 


\section{CONCLUSIONS}

It is recommended that MGR equipment that involves new and unproven technical approaches be development tested prior to final design and procurement. If the specific equipment items are not tested prior to detail design, these equipment items could potentially fail to operate as designed. Equipment failure presents a risk to the MGR program.

Risk pertains to the ability of the MGR to be licensed, constructed, and operated safely (ALARA, industrial, etc.), reliably, and with sufficient capacity (throughput). The consequence of equipment failure could result in substantial cost for equipment repair or replacement, schedule delays or correction of design/facilities. Consequence could be characterized by reduced MGR performance if the design problem is not corrected.

A list of MGR surface equipment that is the responsibility of the M\&O Surface Design Department, based on the VA design, was compiled and evaluated against screening criteria for the purpose of selecting equipment for development testing (See Table I-1). The resulting equipment was further evaluated and qualitatively scored with regard to probability of failure, consequence of failure, program risk, and cost of testing. The results, presented in Table 7-3, identify candidate MGR equipment that is recommended for development testing. A brief discussion of the testing functions for each candidate equipment item is presented in Section 7.2. The candidate equipment and the associated test functions are considered tentative until a survey of similar testing at national laboratories and nuclear facilities has been performed. In addition, ongoing MGR development efforts to provide a final LA design, including alternative studies, etc., may result in design changes in the MGR surface facilities, waste handling systems, and waste handling equipment.

During final MGR LA design, additional surface waste handling equipment and operations, such as cooling of shipping casks and dual-purpose canisters (DPCs) prior to pool entry; decontamination of shipping casks and disposal containers (DCs); and recovery systems for various equipment, will be identified. As these designs are developed and added to the MGR surface equipment, the development test requirements and test functions for these items will be identified and documented.

Future work pertaining to development of MGR surface equipment development tests includes:

a. Survey of updated configurations of MGR facilities, systems, and equipment and confirmation of candidate equipment items for development testing, using updated screening criteria and evaluation criteria.

b. Development of high-level test functions and criteria based on candidate equipment. 
c. Survey of testing of similar technology and equipment that has been performed for other programs at other locations.

d. Identification of development tests that can be integrated.

e. Development of test plans.

f. Identification of candidate test sites. 
Attachment I

MGR Surface Waste Handling System Equipment List

Table 1-1. MGR Surface Waste Handling System Equipment List

\begin{tabular}{|c|c|c|c|c|c|}
\hline System & Equipment No. & Equipment Description & \begin{tabular}{|l|} 
Development \\
Testing \\
Required
\end{tabular} & Criteria & Remarks \\
\hline \multicolumn{6}{|c|}{ Waste Handling Systems Equipment } \\
\hline SU08 & $\mathrm{CH}-\mathrm{CN}-100$ & $\begin{array}{l}\text { Carrier Preparation Bridge } \\
\text { Crane }\end{array}$ & & & \\
\hline SU08 & $\mathrm{CH}-\mathrm{CN}-101$ & $\begin{array}{l}\text { Gantry Mounted } \\
\text { Manipulator }\end{array}$ & & & \\
\hline SU08 & $\mathrm{CH}-\mathrm{FX}-100$ & $\begin{array}{l}\text { Impact Limiter Sling and } \\
\text { Spreader Bar }\end{array}$ & & & \\
\hline SU09 & PH-CN-100 & Carrier Bay Bridge Crane & & & \\
\hline SU09 & PH-EM-100 & $\begin{array}{l}\text { Gantry Mounted } \\
\text { Manipulator }\end{array}$ & & & \\
\hline SU09 & PH-FX-100 & Cask Lifting Yoke & & & \\
\hline SU10 & PU-CA-114 & Assembly Handling Basket & & & \\
\hline SU10 & PU-CA-115 & Assembly Handling Basket & & & \\
\hline SU10 & PU-CA-121 & Large DPC Overpack & & & \\
\hline SU10 & PU-CA-122 & Small DPC Overpack & & & \\
\hline SU10 & PU-CA-127 & Assembly Handling Basket & & & \\
\hline SU10 & PU-CN-110 & $\begin{array}{l}\text { Cask Unloading Area } \\
\text { Bridge Crane }\end{array}$ & & & \\
\hline SU10 & PU-CN-113 & $\begin{array}{l}\text { Assembly Handling Cell } \\
\text { Bridge Crane }\end{array}$ & & & \\
\hline SU10 & PU-CR-110 & Cask Transfer Cart & $x$ & e & \\
\hline SU10 & PU-CR-111 & Incline Transfer Canal Cart & $x$ & e & \\
\hline SU10 & PU-CR-112 & DC Transfer Cart & $x$ & e & \\
\hline SU10 & PU-CR-113 & $\begin{array}{l}\text { Cross-Line Transfer Canal } \\
\text { Cart }\end{array}$ & $x$ & e & \\
\hline SU10 & PU-DC-112 & DC Decontamination Tool & $x$ & b & \\
\hline SU10 & PU-DE-111 & $\begin{array}{l}\text { DC Load Port Mating } \\
\text { Device }\end{array}$ & & & \\
\hline SU10 & PU-DE-116 & DC Lid Lifting Device & $x$ & $a$ and $b$ & \\
\hline SU10 & PU-DE-119 & $\begin{array}{l}\text { DC Inner Lid Sealing } \\
\text { Device }\end{array}$ & $x$ & $a$ and $b$ & \\
\hline
\end{tabular}




\section{Attachment I}

MGR Surface Waste Handling System Equipment List

Table 1-1. MGR Surface Waste Handling System Equipment List

\begin{tabular}{|c|c|c|c|c|c|}
\hline System & Equipment No. & Equipment Description & \begin{tabular}{|l|} 
Development \\
Testing \\
Required
\end{tabular} & Criteria & Remarks \\
\hline SU10 & PU-EM-110 & $\begin{array}{l}\text { Cask Preparation } \\
\text { Manipulator and Special } \\
\text { Tooling }\end{array}$ & $x$ & $a$ and $b$ & \\
\hline SU10 & PU-EM-111 & $\begin{array}{l}\text { Assembly Handling Cell } \\
\text { Manipulator }\end{array}$ & & & \\
\hline SU10 & PU-EM-112 & $\begin{array}{l}\text { DC Decontamination } \\
\text { Manipulator }\end{array}$ & $x$ & $\mathrm{~b}$ & \\
\hline SU10 & PU-EM-113 & DC Inerting Manipulator & $x$ & $a, b$, and $c$ & \\
\hline SU10 & PU-FT-110 & $\begin{array}{l}\text { DC Decontamination Pass- } \\
\text { Thru }\end{array}$ & & & \\
\hline SU10 & PU-FX-100 & Dry Cask Lifting Yoke & & & \\
\hline SU10 & PU-FX-101 & Wet Cask Lifting Yoke & & & \\
\hline SU10 & PU-FX-110 & Cask Lid Lifting Fixture & & & \\
\hline SU10 & PU-FX-111 & $\begin{array}{l}\text { Dry Assembly Lifting } \\
\text { Grapples }\end{array}$ & $x$ & $b$ & \\
\hline SU10 & PU-FX-112 & $\begin{array}{l}\text { DPC/Assembly Basket } \\
\text { Lifting Rod }\end{array}$ & & & \\
\hline SU10 & PU-FX-113 & $\begin{array}{l}\text { Wet Assembly Lifting } \\
\text { Grapples }\end{array}$ & $x$ & $b$ & \\
\hline SU10 & PU-FX-123 & Large DPC Lifting Fixture & & & \\
\hline SU10 & PU-FX-124 & Small DPC Lifting Fixture & & & \\
\hline SU10 & PU-HA-111 & $\begin{array}{l}\text { Assembly Drying Vessel } \\
\text { Shield Plug }\end{array}$ & & & \\
\hline SU10 & PU-HA-112 & DC Load Port Shield Plug & & & \\
\hline SU10 & PU-MA-112 & $\begin{array}{l}\text { Wet Assembly Transfer } \\
\text { Machine }\end{array}$ & $x$ & b & \\
\hline SU10 & PU-MA-115 & $\begin{array}{l}\text { Dry Assembly Transfer } \\
\text { Machine }\end{array}$ & $x$ & $\sqrt{b}$ & \\
\hline SU10 & PU-ME-110 & $\begin{array}{l}\text { Large DPC Lid Severing } \\
\text { Tool }\end{array}$ & $\bar{x}$ & $a, b, c$, and $d$ & \\
\hline SU10 & PU-ME-112 & $\begin{array}{l}\text { Small DPC Lid Severing } \\
\text { Tool }\end{array}$ & & & $\begin{array}{l}\text { Technical } \\
\text { approach } \\
\text { demonstrated on } \\
\text { PU-ME-110 }\end{array}$ \\
\hline SU10 & PU-SR-110 & Basket Staging Racks & & & \\
\hline SU11 & PC-CN-110 & Canister Cell Bridge Crane & & & \\
\hline SU11 & PC-CR-110 & Cask Transfer Cart & $x$ & e & \\
\hline
\end{tabular}


Attachment I

MGR Surface Waste Handling System Equipment List

Table 1-1. MGR Surface Waste Handling System Equipment List

\begin{tabular}{|c|c|c|c|c|c|}
\hline System & Equipment No. & Equipment Description & $\begin{array}{l}\text { Development } \\
\text { Testing } \\
\text { Required }\end{array}$ & Criteria & Remarks \\
\hline SU11 & PC-CR-111 & DC Transfer Cart & $\mathrm{X}$ & e & \\
\hline SU11 & PC-EM-110 & $\begin{array}{l}\text { Cask Preparation } \\
\text { Manipulator and Special } \\
\text { Tooling } \\
\end{array}$ & & & $\begin{array}{l}\text { Identical to } \\
\text { PU-EM-110 }\end{array}$ \\
\hline SU11 & PC-EM-111 & \begin{tabular}{|l} 
Canister Transfer \\
Manipulator
\end{tabular} & & & \\
\hline SU11 & PC-FX-110 & Cask Lid Lifting Fixture & & & \\
\hline SU11 & PC-FX-111 & $\begin{array}{l}\text { Large Canister Lifting } \\
\text { Fixtures }\end{array}$ & & & \\
\hline SU11 & PC-FX-111A & $\begin{array}{l}\text { Small Canister Lifting } \\
\text { Fixtures }\end{array}$ & & & \\
\hline SU11 & PC-FX-112 & $\begin{array}{l}\text { DHLW/DOE SNF Canister } \\
\text { Lifting Fixtures }\end{array}$ & & & \\
\hline SU11 & PC-SR-110 & $\begin{array}{l}\text { DHLW/DOE SNF Canister } \\
\text { Staging Rack }\end{array}$ & & & \\
\hline SU12 & PR-CR-100 & WPRC Transfer Cart & $\bar{x}$ & e & \\
\hline SU12 & PR-DC-100 & WPRC Decon Device & & & \\
\hline SU12 & PR-EM-100 & WPRC Manipulator & & & \\
\hline SU12 & PR-ME-101 & WPRC Cutting Machine & $x$ & $a, b$, and $c$ & \\
\hline SU13 & PD-CN-100 & DC Cell Bridge Cranes & & & \\
\hline SU13 & PD-CN-102 & $\begin{array}{l}\text { DC Welding Station Jib } \\
\text { Crane }\end{array}$ & $x$ & $a$ and $b$ & \\
\hline SU13 & PD-CN-104 & $\begin{array}{l}\text { Empty DC Preparation } \\
\text { Bridge Crane }\end{array}$ & & & \\
\hline SU13 & PD-CN-105 & $\begin{array}{l}\text { Welder Maintenance Cell } \\
\text { Bridge Crane }\end{array}$ & & & \\
\hline SU13 & PD-CN-106 & $\begin{array}{l}\text { DC Transporter Load Cell } \\
\text { Bridge Crane }\end{array}$ & & & \\
\hline SU13 & PD-CR-100 & DC Horizontal Transfer Cart & $x$ & $a, b$, and $c$ & \\
\hline SU13 & PD-CR-101 & Empty DC Transfer Cart & $x$ & e & \\
\hline SU13 & PD-CR-102 & DC Cell Service Cart & & & \\
\hline SU13 & PD-CR-103 & $\begin{array}{l}\text { DC Handling Collar } \\
\text { Transfer Tunnel Cart }\end{array}$ & & & \\
\hline SU13 & PD-DC-100 & $\begin{array}{l}\text { DC Decontamination } \\
\text { Device }\end{array}$ & & & \\
\hline SU13 & PD-EM-101 & $\begin{array}{l}\text { DC } \\
\text { Decontamination/Inspection }\end{array}$ & $x$ & $\mathrm{~b}$ & \\
\hline
\end{tabular}




\section{Attachment I}

- MGR Surface Waste Handling System Equipment List

Table I-1. MGR Surface Waste Handling System Equipment List

\begin{tabular}{|c|c|c|c|c|c|}
\hline System & Equipment No. & Equipment Description & $\begin{array}{l}\text { Development } \\
\text { Testing } \\
\text { Required }\end{array}$ & Criteria & Remarks \\
\hline & & Manipulator & & & \\
\hline SU13 & PD-EM-102 & $\begin{array}{l}\text { DC Welding Station } \\
\text { Manipulator }\end{array}$ & & & \\
\hline SU13 & PD-FX-100 & DC Lifting Yoke & & & \\
\hline SU13 & PD-FX-101 & DC Staging Stand & & & \\
\hline SU13 & PD-FX-103 & DC Tilting Fixture & & & \\
\hline SU13 & PD-FX-104 & Empty DC Lifting Yoke & & & \\
\hline SU13 & PD-FX-105 & Empty DC Lifting Beam & & & \\
\hline SU13 & PD-FX-106 & Empty DC Tilting Fixture & & & \\
\hline SU13 & PD-FX-107 & Empty DC Support Saddle & & & \\
\hline SU13 & PD-FX-119 & DC Lifting Collar & $x$ & $a, b$, and $c$ & \\
\hline SU13 & PD-FX-120 & DC Base Collar & $x$ & $a, b$, and $c$ & $\begin{array}{l}\text { Technical } \\
\text { approach } \\
\text { demonstrated on } \\
\text { PD-FX-119 }\end{array}$ \\
\hline SU13 & PD-MA-100 & $\begin{array}{l}\text { DC Horizontal Lifting } \\
\text { Machine }\end{array}$ & $x$ & $a, b$, and $c$ & \\
\hline SU13 & PD-ME-100 & $\begin{array}{l}\text { DC Inner Lid Sealing } \\
\text { Device }\end{array}$ & & & \\
\hline SU13 & PD-ME-101 & $\begin{array}{l}\text { DC Welding/Inspection } \\
\text { Machine }\end{array}$ & $x$ & & \begin{tabular}{|l|} 
Current \\
prototype \\
development
\end{tabular} \\
\hline SU13 & PD-ME-102 & $\begin{array}{l}\text { DC Welding Station } \\
\text { Turntable }\end{array}$ & & & \\
\hline SU13 & PD-ME-103 & $\begin{array}{l}\text { DC Inner Lid Alignment } \\
\text { Device }\end{array}$ & & & \\
\hline SU51 & AR-CN-100 & $\begin{array}{l}\text { Transfer Corridor Bridge } \\
\text { Crane }\end{array}$ & & & \\
\hline SU51 & AR-CN-110 & $\begin{array}{l}\text { DC Cell Transfer Corridor } \\
\text { Bridge Crane }\end{array}$ & & & \\
\hline SU13 & PD-FX-121 & $\begin{array}{l}\text { DC Handling Collar Storage } \\
\text { Stand }\end{array}$ & & & \\
\hline SU13 & PD-FX-122 & $\begin{array}{l}\text { DC Handling Collar Storage } \\
\text { Module }\end{array}$ & & & \\
\hline SU13 & PD-FX-123 & $\begin{array}{l}\text { DC Lid and Seal/Alignment } \\
\text { Device Grapple }\end{array}$ & & & \\
\hline SU13 & PD-FX-124 & $\begin{array}{l}\text { DC Liffing Yoke Storage } \\
\text { Stand }\end{array}$ & & & \\
\hline
\end{tabular}


Attachment 1

MGR Surface Waste Handling System Equipment List

\begin{tabular}{|c|c|c|c|c|c|}
\hline System & Equipment No. & Equipment Description & \begin{tabular}{|l|} 
Development \\
Testing \\
Required \\
\end{tabular} & Criteria & Remarks \\
\hline \multicolumn{6}{|c|}{ Waste Handling Building Structural Equipment } \\
\hline SU02 & PU-DO-110 & Airlock Isolation Door & & & \\
\hline SU02 & PU-DO-112 & $\begin{array}{l}\text { Assembly Cell Crane Maint. } \\
\text { Isolation Door }\end{array}$ & & & \\
\hline SU02 & PU-HA-110 & Pool Area Access Hatch & & & \\
\hline SU02 & PU-HA-112 & $\begin{array}{l}\text { Assembly Cell Crane Maint. } \\
\text { Access Hatch }\end{array}$ & & & \\
\hline SU02 & PU-DO-113 & DC Load Cell Shield Door & & & \\
\hline SU02 & PU-DO-114 & DC Decon Shield Door & & & \\
\hline SU02 & PC-DO-110 & Airlock Isolation Door & & & \\
\hline SU02 & PC-DO-111 & Prep/Decon Isolation Door & & & \\
\hline$\widehat{\text { SU02 }}$ & PC-DO-112 & $\begin{array}{l}\text { Canister Transfer Cell } \\
\text { Shield Door }\end{array}$ & & & \\
\hline SU02 & PC-DO-113 & DC Load Shield Door & & & \\
\hline SU02 & PC-WO-111 & DC Load Shield Window & & & \\
\hline SU02 & PC-DO-114 & $\begin{array}{l}\text { Crane Maintenance Shield } \\
\text { Door }\end{array}$ & & & \\
\hline SU02 & PC-HA-110 & $\begin{array}{l}\text { Crane Maintenance Access } \\
\text { Hatch }\end{array}$ & & & \\
\hline SU02 & PD-DO-100 & $\begin{array}{l}\text { DC Welding Station Shield } \\
\text { Door }\end{array}$ & & & \\
\hline SU02 & PD-D0-101 & $\begin{array}{l}\text { DC Cell WP Exit Shield } \\
\text { Door }\end{array}$ & & & \\
\hline SU02 & PD-HA-100 & DC Cell Transfer Hatch & & & \\
\hline SU02 & PD-DO-106 & $\begin{array}{l}\text { DC Cell Crane Maintenance } \\
\text { Isolation Door }\end{array}$ & & & \\
\hline SU02 & PD-HA-101 & $\begin{array}{l}\text { DC Cell Crane Maintenance } \\
\text { Access Hatch }\end{array}$ & & & \\
\hline SU02 & PD-D0102 & WP Load Shield Door & & & \\
\hline SU02 & PD-FT-100 & $\begin{array}{l}\text { WP Decon/Load Pass } \\
\text { Through }\end{array}$ & & & \\
\hline SU02 & PD-DO-103 & WP Airlock Isolation Door & & & \\
\hline SU02 & PC-WO-110 & $\begin{array}{l}\text { Cask Prep Shielding } \\
\text { Window }\end{array}$ & & & \\
\hline
\end{tabular}


Attachment I

MGR Surface Waste Handling System Equipment List

\begin{tabular}{|c|c|c|c|c|c|}
\hline System & Equipment No. & Equipment Description & $\begin{array}{l}\text { Development } \\
\text { Testing } \\
\text { Required }\end{array}$ & Criteria & Remarks \\
\hline SU02 & PU-WO-110 & $\begin{array}{l}\text { Cask Prep Shielding } \\
\text { Window }\end{array}$ & & & \\
\hline SU02 & PU-WO-111 & $\begin{array}{l}\text { Assembly Cell Shielding } \\
\text { Window }\end{array}$ & & & \\
\hline SU02 & PU-WO-112 & $\begin{array}{l}\text { DC Load Cell Shielding } \\
\text { Window }\end{array}$ & & & \\
\hline SU02 & PU-WO-113 & $\begin{array}{l}\text { DC Decon Cell Shielding } \\
\text { Window }\end{array}$ & & & \\
\hline SUO2 & PD-WO-100 & DC Cell Shielding Window. & & & \\
\hline SUO2 & PD-WO-101 & $\begin{array}{l}\text { WP Decon Cell Shielding } \\
\text { Window }\end{array}$ & & & \\
\hline SU02 & PR-DO-100 & WPRC Shield Door & & & \\
\hline SU02 & PR-D0-101 & $\begin{array}{l}\text { WPRC Crane Maint. Shield } \\
\text { Door }\end{array}$ & & & \\
\hline SU02 & PR-HA-100 & WPRC Access Hatch & & & \\
\hline SU02 & PR-WO-100 & WPRC Shielding Window & & & \\
\hline SU02 & AR-HA-100 & Transfer Corridor Exit Hatch & & & \\
\hline SU02 & PD-HA-100 & $\begin{array}{l}\text { DC Cell Transfer Corridor } \\
\text { Exit Hatch }\end{array}$ & & & \\
\hline SUO2 & PD-DO-104 & $\begin{array}{l}\text { Empty DC Airlock Shield } \\
\text { Door }\end{array}$ & & & \\
\hline SU02 & PD-DO-105 & $\begin{array}{l}\text { Empty DC Airlock Isolation } \\
\text { Door }\end{array}$ & & & \\
\hline SU10 & PU-V-110 & Spent Fuel Drying Vessel & & & \\
\hline
\end{tabular}


Attachment I

MGR Surface Waste Handling System Equipment List

\begin{tabular}{|l|l|l|l|l|l|}
\hline System & Equipment No. & Equipment Description & $\begin{array}{l}\text { Development } \\
\text { Testing } \\
\text { Required }\end{array}$ & Criteria & Remarks \\
\hline Waste Handling Building Pool Equipment & \multicolumn{2}{|l|}{} & \\
\hline SU10 & PU-PU-100 & Pool Water Pump & & \\
\hline SU10 & PU-FL-100 & Pool Primary Filter & & \\
\hline SU10 & PU-DM-100 & Ion Exchange Unit & & \\
\hline SU10 & PU-FL-101 & Secondary Pool Filter & & & \\
\hline SU10 & PU-UV-100 & UV Sterilizer & & \\
\hline SU10 & PU-TK-100 & Holding Tank (Backwash) & & & \\
\hline SU10 & PU-ME-110 & $\begin{array}{l}\text { Pool Vacuum Cleaner } \\
\text { Equipment }\end{array}$ & & & \\
\hline SU10 & PU-PU-102 & Pool Cooler Pump & & & \\
\hline SU10 & PU-E-100 & Pool Water Cooler & & & \\
\hline SU10 & PU-CH-100 & Chiller & & \\
\hline SU10 & PU-FL-102 & Cask Vent HEPA Filter & & & \\
\hline SU10 & PU-FL-103 & Cask Vent Carbon Filter & & & \\
\hline
\end{tabular}


Attachment I

MGR Surface Waste Handling System Equipment List

\begin{tabular}{|c|c|c|c|c|c|}
\hline System & Equipment No. & Equipment Description & $\begin{array}{l}\text { Development } \\
\text { Testing } \\
\text { Required } \\
\end{array}$ & Criteria & Remarks \\
\hline \multicolumn{6}{|c|}{ Waste Treatment Building Equipment } \\
\hline & RH-BL-101 & Vent Blower & & & \\
\hline & RH-BL-201 & Blower & & & \\
\hline & RH-BL-202 & Vent Blower & & & \\
\hline & RH-CN-201 & Portable Jib Crane & & & \\
\hline & RH-DM-101 & ION Exchanger Columns & & & \\
\hline & RH-E-101 & Overhead Condenser & & & \\
\hline & RH-E-102 & Heater & & & \\
\hline & RH-E-201 & Heater & & & \\
\hline & RH-FL-101 & Cartridge Filter & & & \\
\hline & RH-FL-102 & Roughing Filter & & & \\
\hline & RH-FL-103 & HEPA Filter & & & \\
\hline & RH-FL-201 & HEPA Filter & & & \\
\hline & RH-FL-202 & Roughing Filter & & & \\
\hline & RH-FL-203 & HEPA Filter & & & \\
\hline & RH-ME-101 & Caustic Injection Skid & & & \\
\hline & RH-ME-102 & Acid Injection Skid & & & \\
\hline & RH-ME-103 & $\begin{array}{l}\text { Chemical Waste Drum } \\
\text { filling Station }\end{array}$ & & & \\
\hline & RH-ME-104 & Cement Silo & & & \\
\hline & RH-ME-105 & Rotary Feeder & & & \\
\hline & RH-ME-106 & Cement Feeder & & & \\
\hline & RH-ME-107 & Cement Mixing Station & & & \\
\hline & RH-ME-108 & $\begin{array}{l}\text { Spent Resin Drum Filling } \\
\text { Station }\end{array}$ & & & \\
\hline
\end{tabular}


Attachment I

MGR Surface Waste Handling System Equipment List

\begin{tabular}{|c|c|c|c|c|c|}
\hline System & Equipment No. & Equipment Description & \begin{tabular}{|l|} 
Development \\
Testing \\
Required \\
\end{tabular} & Criteria & Remarks \\
\hline & RH-ME-201 & Waste Sorting Station & & & \\
\hline & RH-ME-202 & Press/Cutter & & & \\
\hline & RH-ME-203 & Drum Lifter & & & \\
\hline & RH-ME-204 & Gravity Filtration system & & & \\
\hline & RH-ME-205 & $\begin{array}{l}\text { Waste Size Sorting } \\
\text { Station }\end{array}$ & & & \\
\hline & RH-ME-206 & Drum Handler & & & \\
\hline & RH-ME-207 & Shredding Station & & & \\
\hline & RH-ME-208 & In-Drum Compactor & & & \\
\hline & RH-ME-209 & Supercompactor & & & \\
\hline & RH-ME-210 & Cement Silo & & & \\
\hline & RH-ME-211 & Rotary Feeder & & & \\
\hline & RH-ME-213 & Cement Mixing Station & & & \\
\hline & RH-ME-214 & Drum Lifter & & & \\
\hline & RH-PU-101 & $\begin{array}{l}\text { Chemical Waste Feed } \\
\text { Pump }\end{array}$ & & & \\
\hline & RH-PU-102 & $\begin{array}{l}\text { Recyclable Waste Feed } \\
\text { Pump }\end{array}$ & & & \\
\hline & RH-PU-103 & Evaporator Feed Pump & & & \\
\hline & RH-PU-104 & $\begin{array}{l}\text { ION Exchange Unit Feed } \\
\text { Pump }\end{array}$ & & & \\
\hline & RH-PU-105 & Resin Transfer Pumps & & & \\
\hline & RH-PU-106 & $\begin{array}{l}\text { Spent Resin Transfer } \\
\text { Pumps }\end{array}$ & & & \\
\hline & RH-PU-107 & $\begin{array}{l}\text { Recycle Water Supply } \\
\text { Pump }\end{array}$ & & & \\
\hline & RH-PU-109 & $\begin{array}{l}\text { Treated Chemical Waste } \\
\text { Transfer Pump } \\
\end{array}$ & & & \\
\hline & RH-PU-110 & $\begin{array}{l}\text { Floor Drain Transfer } \\
\text { Pump }\end{array}$ & & & \\
\hline & RH-PU-111 & Sump Pump & & & \\
\hline & RH-PU-201 & Filtrate Transfer Pump & & & \\
\hline
\end{tabular}




\section{Attachment I}

MGR Surface Waste Handling System Equipment List

\begin{tabular}{|c|c|c|c|c|c|}
\hline System & Equipment No. & Equipment Description & $\begin{array}{l}\text { Development } \\
\text { Testing } \\
\text { Required }\end{array}$ & Criteria & Remarks \\
\hline & RH-SK-210 & $\begin{array}{l}\text { Cement Storage Silo } \\
\text { Package }\end{array}$ & & & \\
\hline & RH-SK-212 & Cement Feeder & & & \\
\hline & RH-TK-101 & $\begin{array}{l}\text { Chemical Liquid LLW } \\
\text { Collection Tank }\end{array}$ & & & \\
\hline & RH-TK-102 & $\begin{array}{l}\text { Recyclable Liquid LLW } \\
\text { Collection Tank }\end{array}$ & & & \\
\hline & RH-TK-103 & Evaporator Feed Tank & & & \\
\hline & RH-TK-104 & $\begin{array}{l}\text { Condensate Collection } \\
\text { Tank }\end{array}$ & & & \\
\hline & RH-TK-105 & Resin Feed Tank & & & \\
\hline & RH-TK-106 & Spent Resin Catch Tank & & & \\
\hline & RH-TK-107 & $\begin{array}{l}\text { Recyclable Water } \\
\text { Storage Tank }\end{array}$ & & & \\
\hline & RH-TK-108 & PH Adjustment Tank & & & \\
\hline & RH-TK-109 & $\begin{array}{l}\text { Floor Drain Collection } \\
\text { Tank }\end{array}$ & & & \\
\hline & $\mathrm{RH}-\mathrm{V}-101$ & Evaporator Package & & & \\
\hline
\end{tabular}

